\title{
18. IGNEOUS ROCK SAMPLES RECOVERED ON LEG 2
}

\author{
A. E. J. Engel and C. G. Engel \\ Scripps Institution of Oceanography, La Jolla, California
}

Basalt and diabase sills were recovered from the bottom of two holes on Leg 2. Two of the samples collected were from Site 10 , latitude $32^{\circ} 52^{\prime} \mathrm{N}$., longitude $52^{\circ}$ $13^{\prime} \mathrm{W}$. The depth of water at this site was $15,406 \mathrm{feet}$ (4697 meters); the depth below the sediment-water interface at which the basaltic sill was cored was 1495 feet (456 meters). The length of the basalt-diabase core recovered was about 60 centimeters.

A third sample was from Hole $11 \mathrm{~A}$, latitude $29^{\circ}$ $57^{\prime} \mathrm{N}$., longitude $44^{\circ} 45^{\prime} \mathrm{W}$. This basaltic sill was drilled in 11,664 feet (3556 meters) of water. Here, the depth below the sediment-water interface at which the basalt was cored was 931 feet ( 284 meters). The length of the basalt-diabase core was about 30 centimeters.

Both of the sills cored in the three holes at the two drilling sites appear to be oceanic tholeiites. This identification is based entirely upon examination with a hand lens and in thin section and it needs chemical confirmation. As per agreement, no analytical work has been done as yet. Neither sill was penetrated by the drill. Both of them have a narrow (up to 2 centimeters) palagonitic to glassy upper contact with the calcium carbonate-rich sediment which has recrystallized and metamorphosed at and within 0.2 to several centimeters above the contact. All cores of both sills are vesicular and incipiently-to-highly-altered, especially to palagonite and to carbonate which occurs in veins and as vesicle fillings, and as disseminated, commonly fine-grained to microcrystalline aggregates in the tholeiitic basalt and diabase. Carbonate comprises from one to perhaps 5 per cent of the ground mass of the sills and forms veins up to one centimeter wide.

The textures and mineralogy of both sills are essentially the same. The glassy upper sill margins adjacent to, and mixed with, carbonate-rich sediment are commonly veined, and are locally almost completely replaced by palagonite. There is no clear-cut correlation between the age of the basalt and the amount of palagonitization.
The least altered glassy sill tops contain abundant elongate laths and needles of plagioclase (labradorite and sodic bytownite) and scattered crudely equant grains of olivine. This glass (up to about 1 centimeter thick) grades abruptly into devitrified and variously crystalline porphyritic basalt (up to 2 centimeters thick) which in turn grades abruptly into very fine-grained to medium-grained diabase, composed largely of labradorite, augite, and opaque mineral oxides with little to no interstitial glass. Olivine is commonly absent or very rare in the interiors of the sills. The vesicles are lined or filled with palagonite, calcite, opaque oxides, devitrified dark glass, rare zeolites and subordinate other minerals.

Frequently, wisps and lenses of finer-and coarser-grained diabase alternate in the core in forms suggestive of pulses of injection, or perhaps multiple injection.

The sample at Hole 11A, Core 7, is the least altered of all the basalt cored. Neither it, nor the other core is completely fresh; and, both total rock analyses and age determinations of these rocks may be only approximate at best. Determining the radioactive age (K/A age) of the plagioclases separated from the rocks is possible, but it is difficult because of fine grain size. Numerous other chemical characteristics of the rocks can be approximated, but the alteration-especially to carbonate-is expected to prevent precise definition of the magma types, abundance distribution patterns of rare earths, $\mathrm{Th} / \mathrm{U}, \mathrm{Sr}^{87} /^{86}, \mathrm{~K} / \mathrm{Rb}$, etc.

The authors anticipate a slightly higher incidence of titanium than that found in most oceanic tholeiites-an inference based upon the deep violet pleochroic colors of the augite therein. Sodium also may be higher than the average for oceanic flows sampled, because of the somewhat slower chilling and opportunities for stewing within oceanic sediments. The presence of the numerous vesicles (up to 1 centimeter in diameter) suggests either emplacement at much shallower depths, or different fluids and fluid pressures than commonly assumed for magmas at these depths. 